\title{
INTELLECTUAL PROPERTY: THE STATE OF THE ART.
}

\author{
Professor David Vaver*
}

This is an address which was presented by Professor David Vaver at Victoria University of Wellington on 30 August 2000. Professor David Vaver was brought to New Zealand by the New Zealand Law Foundation as the Distinguished Visiting Fellow for 2000. This address is based on an inaugural lecture delivered on 17 May 2000, at the Gulbenkian Lecture Theatre, Faculty of Law, University of Oxford and published as "Intellectual Property: The State of the Art" (2000) 116 LQR 621. VUWLR is grateful to the Law Quarterly Review for allowing republication of this address.

I wish to talk about the state of the art in intellectual property - what the law of intellectual property looks like today, and what some of its current difficulties are.

Let me first define my terms, for intellectual property as a phrase is not self-defining. Indeed, the phrase has come into common English language use only within the last two or three decades - a mere twinkling of an eye, so far as legal matters go. Even now, the leading set of American law reports in the field is called the United States Patents Quarterly, although patent cases form just a fraction of its coverage. In the United Kingdom, the USPQ's much longer established counterpart started off in 1884 under the aegis of the UK Patent Office also as the Reports of Patent Cases. Much later, it expanded its title (though not its RPC abbreviation) to correspond with its larger coverage, and became the Reports of Patent, Trade Mark, Design and Other Cases. The mysterious "Other Cases" - the cases that dared not speak their name - included, appropriately enough, the law relating to trade secrets and confidential information, and a rather large category called Copyright. ${ }^{1}$ Interestingly enough, a new set of reports that started in 1966 as the Fleet Street Patent Law Reports eventually became the Fleet Street Reports of

* Reuters Professor of Intellectual Property and Information Technology Law, Oxford University, and Director of the Oxford Intellectual Property Research Centre, St Peter's College.

1 When legal publishers Sweet \& Maxwell Ltd took over the publication of both the Reports of Patent Cases and the Fleet Street Reports, the RPC's long title dropped the "And Other" cases. 
Industrial Property Cases from the Commonwealth and Europe (abbreviated to "FSR"). ${ }^{2}$ It was not until the late 1970s that the European Intellectual Property Review commenced publication in Oxford, followed in the early 1980s by the Intellectual Property Reports and the Intellectual Property Journal emanating respectively from Australia and Canada.

So what is intellectual property? The first thing to note is that, even today, there is no single legal entity going under that name. The phrase is really a handy shorthand for a whole slew of disparate rights - in the Commonwealth: some statutory, some common law, some equitable - which share the feature that they protect some products of the human mind, for varying periods of time, against use by others of those products in various ways. The general purpose of protection is to encourage those who may wish to create, finance or exploit such products to translate intent into act, particularly where they might otherwise not act at all, or act less often or less well, without the carrot of protection.

The most familiar of these rights, and the mainstays of the intellectual property system, are patents, copyrights, and trade marks, but there are quite a few more hangers on and upstarts: design, database, semiconductor topography and plant breeder rights, rights over trade secrets and other confidential information, and various other rights that prevent or redress specific acts of unfair competition.

There is much misunderstanding on what intellectual property's components comprise, even among otherwise knowledgeable people. For example, one hears talk of patents where copyrights are meant, and vice versa, and intellectual property rights also figure loosely in common parlance, viz, Tiger Woods' patented (or, indifferently, trade mark or copyright) golf swing. Such loose usages can have impacts. Thus, around the time of the summer Olympics in Atlanta in 1996, there was speculation in the legal journals that intellectual property rights could be extended to cover sports moves: not just a patent for a new golf club or ball, but for a way of swinging a golf club. ${ }^{3}$ Many a golf game might no doubt be livened up as intellectual property lawyers take to the greens to scrutinize each swing and to serve legal process on whichever player comes close to the bunker of patent law; but the cure for dullness in sporting events is surely better found outside the intellectual property sphere.

So what rights fall under intellectual property, and what is their true terrain?

First there are patents for new, non-obvious and useful inventions - what the first English legislation, the Statute of Monopolies 1624, called "new manners of manufacture".

2 Some sympathy must be felt for any building developer who started subscribing to this series in the belief that industrial property had to do with building construction and zoning.

3 Kunstadt and others "Are Sports Moves Next in IP Law?" National Law Journal (20 May 1996), c1; Phelops "Can Copyright Move in Mysterious Ways?" (1996) 63 Copyright World 17. 
That statute conceded the power of the Crown to grant monopolies for fourteen years in order to encourage the introduction of new trades or inventions into the realm. The current international standard for patents for invention is a twenty-year right preventing everyone within the granting territory from exploiting the invention, even those who might make the same thing independently (and sometimes almost contemporaneously) without knowing of the existence of the earlier invention or patent. In recent years, patents have come to be granted over not only mechanical products and processes, but also new substances and the products of computer and genetic engineering. (Dolly, the cloned sheep, springs to mind.)

Then there is the law of copyright, which traces back to the early eighteenth century, and even earlier to the practices of the English stationers - the printers and publishers of yore. Copyright first protected books and then expanded, through a combination of new legislation and sympathetic interpretation by the courts, to cover art, drama and music. Over the last century, it has come to protect almost anything written, drawn, or expressed in any way against copying: from the most complicated computer program, requiring months of intensive development and sometimes millions of pounds in investment, to the doodles of toddlers and the dashed off internal memorandum. Unlike a patent, copyright protects only against copying, not independent creation, although copying is capaciously construed. Also controlled are acts such as public performance, broadcast, and sometimes even rentals. Copyright lasts a very, very long time. From what started as a maximum of twenty-eight years protection (fourteen years, renewable for another fourteen) in 1710, copyrights today can last automatically for well over a century. The life of the author plus seventy years has become the European and now United States norm. Can a more widespread, even global, change from the more common term of life of the author plus fifty years, long prescribed by the Berne Convention for the Protection of Literary and Artistic Works (Paris revision, 1971), be far behind?

Then there are trade marks. Merchant marks were protected even during the time of the mediaeval guilds, but the modern law of trade marks is really a product of the Industrial Revolution. The law initially stopped only fraudulent imitations but quickly progressed in the nineteenth century to ban innocent confusion, and in the twentieth century even some non-confusing uses. For example, on seeing the distinctive ROLEX watch mark on furniture, few people may be led to believe that the Rolex firm has gone into the furniture business (although anything may now be possible in this era of frequent horizontal corporate diversification) but Rolex may nevertheless be able to stop such a non-confusing third party use. The law is more willing than ever before to recognise that firms have an interest in controlling the imagery with which their brands are associated and in preventing uses that might harm or dilute those associations. With registration and periodical renewal, trade marks last potentially forever, at least as long as they are used or 
maintain some market recognition. Even without registration, such symbols reflecting trade origin may be protected under the general law from those who deliberately or innocently use them to create market confusion or even brand dilution.

And then there is a little entourage of additional newer rights that fill in some of the perceived gaps left in the patents, copyrights and trade marks intellectual property groups. Thus, in the United Kingdom, various statutes and regulations grant rights:

(1) for 50 years to performers;

(2) for between 25 and 35 years to breeders of new varieties of trees and plants, upon examination and registration;

(3) for up to 15 years for designers of new product or semiconductor chip designs, and for up to 25 years (upon examination and registration) for other sorts of product design;

(4) for 15 years for producers of databases (but 15 years is a rolling term that becomes practically perpetual if a substantial investment in time or money is made in keeping the database updated).

Besides that, courts apply the general law to prevent acts of unfair competition - more expansively construed in civil law than in common law countries - and such regional or international organisations as the European Union, the World Intellectual Property Organisation and the World Trade Organisation ("WTO") are engaged in yet further proposals for intellectual property expansion, eg, in the field of designs, minor inventions, performances, films, broadcasts, and sound recordings.

Viewed in historical perspective, this otherwise bewildering array of rights exhibits some common features:

(1) Intellectual property has become ever more important in everyday business life. Few law firms can call themselves major if they lack an intellectual property department, intellectual property partner, or at least a sign on some door saying "Intellectual Property". Few university law, commerce or economic faculties can call themselves serious if they lack offerings in Intellectual Property. Few companies in the media, entertainment, computer or pharmaceutical industries - perhaps even some of the bloated dot.com companies - would have much value on their balance sheets if their intellectual property holdings, or the businesses predicated on them, were factored out. Certainly, Microsoft's recent stock market fluctuations have had less to do with any rise or fall in value of that corporation's bricks and mortar assets, than on predictions about what intellectual property strategies Microsoft may now use to maintain market share after whatever orders are made (and upheld on appeal) to correct its alleged antitrust abuses. 
(2) The subject-matter of intellectual property rights has increased enormously over the years. Patents begat plant breeder rights; copyrights begat performer, design and database rights; design rights begat rights over semiconductor topographies; trade marks are conceiving rights in domain names on the Internet; and the begetting and begatting is far from over.

Similar procreative activity is occurring within the individual intellectual property regimes. The inexorable march of copyright beyond books to cover almost any scratch, squiggle or squawk has its counterpart in trade mark and patent law. Thus, in the United Kingdom, up to the 1980 s only certain categories of trade marks were accepted for registration, but now almost any perceptible symbol may qualify: marks for services as well as goods, words, labels, designs, sounds, perhaps even smells. The special aroma of some Château le Nez may well be a registrable trade mark, although the necessary written description presumably has to be particularised beyond the "a little presumptuous, with a touch of the barnyard" school of wine-writing.

As for patents, parallel developments are seen in the court decisions on what constituted a patentable "manner of new manufacture". New processes, not just products, were quickly brought within the fold of patentable matter, initially so long as they resulted in some sort of saleable product, but that qualification eventually became watered down to non-existence. And to make such process patents effective, the courts extended them to cover the end products as well. So, a new process for making table salt would give its local patent holder the power to stop the import and distribution of salt made offshore by the process, even though the salt itself, as a well-known product, was plainly unpatentable and indistinguishable from salt made by any other process. The European Patent Convention 1973, its implementing statutes (in the UK, the Patents Act 1977), and the patent clauses in the Agreement on Trade-Related Aspects of Intellectual Property Rights including Trade in Counterfeit Goods ("TRIPs"), annexed to the WTO Agreement of 1994, consolidated these trends.

(3) Intellectual property rights have become more intense and all-encompassing. Thus, starting modestly in the eighteenth century to control the unauthorised reprints of books, the law of copyright steadily grew to encompass partial reprints, then subtler forms of imitation, and then expanded exponentially throughout the twentieth century. With each fresh logical step in one direction, a vista of new paths appeared and further steps were taken along them to intensify the rights.

Take a simple example: the concept of copying. In the nineteenth century, copying was regarded quite literally. To translate was not to copy, as Harriet Beecher Stowe discovered mid-century when she asked the US courts to halt the publication of a German language translation of Uncle Tom's Cabin. The court dismissed the claim. The judge thought that anyone putting the two books side by side could immediately see that the German version 
was nothing like the English version, and so not a copy. ${ }^{4}$ Similarly, when the copyright owner of a painting complained that tableaux vivants mimicking it were being staged in London without his authority, the English courts were unimpressed. A tableau vivant was no copy of the painting: try hanging it on a wall. ${ }^{5}$

All that is now overturned. Since the beginning of the twentieth century, changes in the law and in court interpretations insist that no translation, good or bad, can be made, nor may any tableau vivant be staged, without the consent of the copyright owner of the source work. The statutes stop short of requiring a modern Mussorgsky to ask permission of the artists before he sets out to compose today's, no doubt atonal, equivalent of Pictures at an Exhibition. But, significantly, little in current copyright theory would make it illogical to impose that requirement on the composer, or to let artists claim a share in whatever royalties the composition garners from public performances or broadcasts. The capaciousness of the concept of copy (whether or not formally redefined to cover "adaptations" or "derivative works") may be seen in the view recently taken by US courts that running any program in a computer or accessing any Internet site involves making a copy and so is within the control of the copyright owner of the program or website; this, even if the copy is made temporarily and only for technical reasons - i.e., to look at the website - and even if the copy is automatically deleted once the program or site is exited. ${ }^{6}$ Commonwealth and European (including United Kingdom) courts could, without incongruity, reach similar results.

Similarly, in patent law, the courts have moved toward construing patents much as they construe statutes, going beyond the literal words to the perceived purpose of the language. So, from the $1980 \mathrm{~s}$, if not before, it became acceptable to "interpret" a patent claim referring to a load-bearing structure that extended "vertically" to include structures that leaned eight degrees off the vertical. The court reaching that conclusion - the House of Lords, no less - said that any reasonable builder reading the claim in context would understand "vertically" to include such tolerances. ${ }^{7}$ The reasonable builder is, of course, as fictitious a creature as the reasonable man on the Clapham omnibus. Many epithets might be attributed to any real-life builder who spent his time reading patent claims such as the one in question, comprising a single 198-word sentence with two commas, but "reasonable" would not likely be among them. The most interesting part of the court's

4 Stowe v Thomas (1853) 23 Fed Cas 201. See also Vaver "Translation and Copyright: A Canadian Focus" (1994) 16 EIPR 159.

5 Hanfstaengl $v$ Empire Palace [1894] $2 \mathrm{Ch} 1$ (CA), affirmed sub nom. Hanfstaengl $v$ Baines \& Co. [1895] AC 20 (HL).

6 See, for example, MAI Systems Corp v Peak Computer Inc (1993) 991 F 2d 511 (9th cir).

7 Catnic Components Ltd v Hill \& Smith Ltd [1982] RPC 183 (HL). 
decision, nevertheless, remains its approach to interpretation, under which the Leaning Tower of Pisa could, equally reasonably, be renamed the Vertical Tower of Pisa. ${ }^{8}$

(4) Intellectual property rights have become international. Before the mid-nineteenth century, the rights were usually good only for a particular territory and ran only in favour of the state's nationals: recall Charles Dickens' obsession in the nineteenth century with the lack of copyright that his works then had in the United States. But since the end of the nineteenth century, multilateral international treaties have been adopted which compel ratifying states to provide national treatment to other party states and to grant minimum sets of rights. With each treaty revision every generation or so, the minimum levels of protection were raised and more countries were persuaded into join in. The latest and perhaps most significant of those treaties is the WTO Agreement of 1994 with its TRIPs annexe, which entrenched high levels of intellectual property protection worldwide, with procedures to haul offending states before ad hoc courts (so-called "trade panels") and to have economic sanctions imposed if WTO orders are disregarded. A steady stream of intellectual property disputes has come before those panels, and significant changes have been ordered to be made to national intellectual property laws.

Europeans are, of course, enured to the latter process, as the organs of the EU move toward standardizing intellectual property laws on the theory that differential laws create barriers to the smooth working of an internal market. Such moves are proving complicated and rather controversial as member states find increasingly less leeway to develop their own intellectual property policies. EU intellectual property policy has effectively become the intellectual property policy of its member states.

Let me turn now to a set of events that are suggestive of some of the major difficulties facing intellectual property today, what might be called the intellectual crisis of intellectual property.

Take Wednesday, May 10 2000, a pretty average news day, at least to distant observers. The population of India reached or was about to reach a billion, although, understandably, nobody was quite sure when to fire the salute. British troops were getting involved in yet another world trouble spot. John McCain III grudgingly endorsed George Bush Jr for the US presidency. The Euro had its usual day of hiccups on the Exchange. The buyers of the Rover company from BMW were asking themselves whether they had overpaid.

8 Catnic, above n 7. Hidden away as it is in the specialist reports dealing with patent cases, it deserves to be better known among those who insure builders, architects, engineers and surveyors against negligence. Complaints that a building slopes by $8^{\circ}$ when it was represented as being level can be "Catnic-ed" away with a "Don't fuss. It is level. The House of Lords has said so." 
10 May 2000 was a pretty average day in the intellectual property microcosmos too. In retrospect, four events may come to be seen as capturing some of the spirit of the times even after their details are well and truly archived. First came news of the locating of the person who had released the "I Love You" virus the previous week, which had disrupted computers across the world. The suspect was a computer hacker in the Phillippines, who had dropped out of college when his supervisor had rejected a thesis proposal that dealt with a computer program for using other people's passwords to gain free access to the Internet. Through his lawyer, the suspect said the release of the virus was all a mistake but let the gathered reporters in on his views on intellectual property: "The Internet is supposed to be educational so it should be free," he is reported as saying. ${ }^{9}$

A second apparently unrelated event that day underscored the ubiquity of that viewpoint. The New York Times reported on the availability of a computer program called Freenet, which encrypts files so that users may exchange them anonymously on the Internet. Its developer, whose day job was with a small e-commerce firm in London, had built on a project that he had worked on as a student at Edinburgh University. ${ }^{10} \mathrm{He}$ is reported as saying: ${ }^{11}$

If this whole thing catches on, I think that people will look back in 20 to 40 years and look at

the idea that you can own information in the same way as gold or real estate in the same way

we look at witch burning today.

The programmer also had some advice for copyright holders who sought to halt the free movement of digital data: "I have two words for these companies," he said: "Give up." He actually had two more sentences: "There is no way [these companies] are going to stop these technologies. They are trying to plug holes in a dam that is about to burst."12

Coincidentally, one of these anti-dambursters was, that very day across the Atlantic, busy presenting his viewpoint in an interview that appeared on the Internet. The heavy metal band Metallica has sued the operator of a website that allows the downloading of a program which, like Freenet, enables users to swap files but without encryption. Users of the program, called Napster, typically swap music files - that is, sound recordings stored

9 Sharon Buan "Philippine Dropout Says May Have Sent 'Love Bug'" Reuters News Service, Manila, 11 May 2000.

10 I do not pause to inquire whether Edinburgh University itself could assert that it owned the program copyright. The new Intellectual Property rules adopted by Oxford University in 2000 might well allow the University to make that claim against a comparable Oxford student.

11 This quote may read better in its unencrypted version.

12 John Markoff "The Concept of Copyright Fights for Internet Survival" New York Times electronic version, 10 May 2000. 
in their computer hard drives in a compressed format called MP3 - locating the music they want from a directory on the Napster website.

Metallica presented Napster with evidence that over 300,000 people had used the program to exchange Metallica's works without their authority, and claimed that Napster was a contributory infringer of their copyrights by actively encouraging such infringements. Metallica also joined three universities whose servers were being used to swap Napster files. Two universities, Yale and Indiana - no doubt pleased of an excuse to reduce the heavy Napster traffic which was slowing down the movement of more legitimate material, such as administrative memoranda, on the university servers proceeded to block access to the Napster site, and so were dismissed from the suit. The third university, the University of Southern California, continued to allow the use of Napster by students who were not just out to enjoy the music but were seriously discussing the finer points of Metallica as part of their tertiary education.

Meanwhile, Napster lost the first round of the Metallica litigation. On 2 May 2000, a federal court refused to dismiss the case summarily. Although the court did not go far into the merits, Napster's problem seems twofold. First, the program and website were designed to encourage users to copy music and to hand over electronic copies to others, without the consent of any copyright owner and without paying any royalty. The first commandment of copyright is "Thou shalt not copy without the copyright owner's prior consent." The first user who copied the initial work into her computer and the second user who copied that copy into his machine both broke that rule. Second, Napster may not itself have done any copying, but it may have actively encouraged others to copy by providing a directory of copiable music, and by providing the means of copying. It may not claim innocence of copyright violations once the copyright holder notifies it of what is going on. To operate legally, Napster may perhaps not need to check that every title that it files on its directory has been cleared for copying by the rightholders, but it must at least act to prevent infringement on being notified. Alternatively, it may have to make some prior arrangement with the copyright owners to remit agreed royalties. And, indeed, such a development subsequently occurred. In July, the American record industry managed to obtain a pretrial injunction against Napster in a similar suit but the order was temporarily suspended by a federal appeal court to allow it to hear fuller argument. No decision was available at time of writing. However, in October Napster reached an agreement with one of the plaintiffs, music publisher Bertelsmann, to make the publisher's repertoire available through Napster for users to download on payment of a fee. Bertelsmann consequently dropped out of the litigation. How far users will prefer to pay for authorised repertoire instead of swapping files for free remains to be seen.

Meanwhile, to return to the earlier events of May: Recognising its immediate dilemma, on 10 May Napster closed the offending 300,000 accounts to a mounting barrage of 
criticism from Metallica fans. Later that day, Metallica's co-founder sought to justify the ways of Metallica to ABC News. Among the things he said was the following: ${ }^{13}$

[People are] taking the computer for granted to the point where now [they] believe that they have a right to get music, literature, art and other things for free over the Internet because they have access to them. And, that's a very, very dangerous train of thought, .. that [if] not challenged in the next couple of years .. has the potential to run completely amok, and throw commerce and creative entities and the way people relate to those completely upside down.

One need not be Manichean to sense the intellectual crisis posed to intellectual property by the dicta of the Love Bug spreader, the Freenet programmer, and the Metallica band member. That intellectual crisis is not new or recent. It has existed for centuries, at least since the printing press revolutionised the way in which ideas were disseminated. The crisis has returned to sight periodically as new technologies produced new practices and encroached on former habits and casts of mind.

Digital technology is just the latest manifestation of intellectual property's continual crisis. While business and governments have put much effort into trying to strengthen the copyright system - tightening copyright owners' control over electronic activity, adapting copyright rules to achieve that goal, and shrinking the scope of the public domain - the technology itself has questioned the practicality of these endeavours. After all, copyright, as traditionally conceived, is premised on the initial production of a tangible original work, which is then exploited either through mass marketing of copies, public performance, or broadcast. Unauthorised intrusions into this market are usually relatively quick and easy (though sometimes costly) to detect and to close down through the use of civil or criminal sanctions. But as existing works are digitised, with or without authorisation, or new works are made available solely in digital format, copyright becomes less able to cope with the manipulation and movement of intangible electronic streams. Detection and enforcement become difficult, sometimes impossible, and rights that appear on the books are ignored in practice. Access to music, art, literature, and other material in digital form has given users the power to modify these works or data at will, replicate them almost infinitely, and transmit them anywhere in the world to others, who in turn have the same capabilities; and power, once given, will inevitably be used. In this world, every user is a potential reauthor and re-distributor of material made available electronically to her. In this world, the only way in which an initial provider of a work or information can practically profit from its investment may be through reliance on shared ethical understandings, encryption and

13 "Metallica Co-Founder Lars Ulrich Speaks Out about Napster Copyright Infringement Lawsuit on SamDonaldson@ABCNEWS.com Webcast, 10 May 2000 (Business Wire), viewed on Reuters News 2000 service. 
password technology, click-on contracts, and good marketing (eg, the provision of services like help lines and regular updates to which users wish to subscribe). ${ }^{14}$

Even before digital technology raised such issues, intellectual property was having difficulty justifying itself to its users. How far should right holders be legally able to control how their creations are used or distributed? What qualifies as "their" "creations"? When and what sort of rights should be granted over these creations, and to whom? Such questions highlight the intellectual property system's fundamental incoherence.

Consider the following random examples:

(1) Why should, on the one hand, a toddler's doodles be vigorously protected by copyright from being copied by anyone in any medium whatever for almost any purpose, not only for the period that the toddler grows up and eventually dies, but for seventy years beyond that, while, on the other hand, a life-saving new invention costing millions to research and develop before it can come to market is protected for just twenty years, and in practice often much less? Is encouraging children to be creative somehow worthier than preserving their health or life?

(2) Why do some rights arise and exist automatically and are recognised worldwide, while others exist only if first approved and granted by a state or regional authority, and then are good only within that region?

(3) Are we sure that much of what the law vigorously protects would not have been created anyway, with no, or at least much less vigorous, protection? In crude terms, would I write less or worse letters or articles if my work was protected for, say, only ten years? Or even not protected at all? Some judges believe that the opinions they write are covered by copyright. Is it plausible to think that they would stop writing judgments altogether or drop the quality of what they do write if their opinions had no copyright? On this point at least, we have good empirical evidence. In the United States, no court opinion is protected by copyright. The reams of opinions pouring out of American courts daily - no fewer, shorter or worse than those of courts in jurisdictions where the opinions may be copyright - is eloquent evidence of intellectual property's irrelevance as an incentive in at least one class of case. The intriguing question is: how many more classes of case like this are there?

(4) Quite recently, the English Court of Appeal said that a newspaper which published stills taken from a surveillance camera infringed copyright in the

14 This paragraph is drawn from Vaver Intellectual Property: Copyright, Patents, Trade-marks (Irwin Law, Canada, 1997) 274-5. 
surveillance film. ${ }^{15}$ Do we believe that the use of surveillance cameras would drop if such films had no copyright at all? Perhaps the films should be protected for reasons of privacy; but, if so, should not privacy be protected directly, rather than obliquely and erratically through copyright?

(5) Suppose I provide a medical researcher with a sample of my body tissue. She isolates a gene from it which helps cure cancer, and patents the gene. Under current law, I probably have no legal claim to share in the patent or any royalties flowing from its exploitation, as I have invented nothing. ${ }^{16}$ And yet, without my participation, the cure would not have been found at all or as soon. Do I not have at least a moral claim to some share in the patent? Given the sort of trivia to which intellectual property law does accord rights, why does it turn away its face here?

Such questions assume a North-South geopolitical dimension if the tissue provider is a remote villager in a developing country and the researcher is a bioprospector working on behalf of some pharmaceutical laboratory in the developed world. Developing countries complain that the international intellectual property system developed by the West to suit its interests, and now imposed on the rest of the world through TRIPs and the WTO Agreement, pays little regard to the developing world's special concerns in its genetic resources and traditional knowledge. In the hands of developing countries, these resources are treated as the common heritage of mankind; but when taken, manipulated and repackaged, they become the intellectual property of the Western world.

Let us return to the term "intellectual property". In what sense is intellectual property "intellectual"? Only at the most trivial level, if we ask the question in relation to an automatically running surveillance camera. Certainly, positioning a camera and inserting a video disk seem no more intellectual than positioning one's body to have a sample of body tissue removed. Little more intellectual effort goes into composing a routine threesentence business letter, long ago decided to be an original literary work in English law. ${ }^{17}$ Someone's intellect was no doubt engaged in some way to create the idea and form of the letter. But this kind and level of activity can hardly justify protecting the product against copying for well over a century.

Similarly with patents: most inventions do involve intellectual activity and some breakthroughs may even look like flashes of genius. But most inventions are just fairly

Hyde Park Residence Ltd v Yelland [2000] ECDR 275 (CA).

16 Moore v Regents of the University of California (1990) 793 P 2d 479 (Cal SC).

17 Tett Brothers Ltd v Drake \& Gorham Ltd [1928-1935] MacG Cop Cas 492. 
modest improvements on existing products or processes. Swamped by the thousands of applications that are filed every month, patent offices can do little more than reject the clearly obvious ones and leave competitors to attack, before patent office tribunals or courts, those patents that prove real obstacles in the marketplace. Many patents will thus go unchallenged because it is cheaper to pay a royalty than to risk often tens of thousands of pounds in seeking to overturn them.

The "property" part of intellectual property is equally problematic. Normative arguments, that the creation of something new from raw material available to all justifies the grant of a property right, go only part of the way. The vivid maxim - made all the more powerful because of its biblical antecedents - that as you sow, so you should reap, may work well in matters agricultural but less so in matters intellectual. If I create a new chair design, the maxim produces no logical proposition about the sort of rights I should reap from my creation. Should I be able to stop imitators or independent creators? Should I just be compensated with a royalty for whatever efforts they borrow from me? (Conversely, should I not pay some tribute to my forebears in design, on whose intellectual shoulders I have climbed?) Should my property last for five years, a century, or forever? Everywhere in the world, or just in my country or county? On complying with no formalities, or upon registration or the marking of my chair with some magic symbol to give the world notice of my claim of rights? Or should I just be eligible for a prize from the Society of Good Chair Designers?

One might, of course, counter such arguments by saying that intellectual property is used only metaphorically, and that metaphors should drive neither law nor policy. I agree, but would observe that the process of reification - treating intellectual property as a thing and deducing principles from its "thing-ness" - has become so entrenched internationally among this generation of lawyers and lawmakers as to have become its own state of the art. ${ }^{18}$ The United Nations bureau in charge of the field calls itself the World Intellectual Property Organisation. Intellectual property's international framework is now found in the TRIPs Agreement, the IP abbreviation of which refers to Intellectual Property. The terminology of intellectual property is used constantly throughout that Agreement.

The reification of intellectual property has advantages in creating an analytical framework of sorts for otherwise heterogeneous fields. But it also promotes tendencies that are not always self-evidently positive. Thus:

18 To similar effect, Fisher "The Growth of Intellectual Property: A History of the Ownership of Ideas in the United States" (1999) <http:// eon.law.harvard.edu / property/history.html>. 
(1) Treating the rights as property causes legislatures to structure their intellectual property laws in a particular way, and tribunals to interpret them similarly. The laws grant people called owners a broad set of rights over a broad category of matter: for example, the right to exploit an invention for a given time. This terrain is called the owner's property. Any qualification of that broad right - for example, by saying what items do not qualify as inventions - is treated as an exception. The grant of property is then interpreted broadly; any qualification is interpreted narrowly.

This value system is evident in European patent law. The European Patent Convention 1973, in articles 52 and 53, excluded a miscellany of things from patentability for policy reasons: discoveries, scientific theories, business schemes, computer programs, methods for treating humans or animals by surgery or therapy, inventions the exploitation of which would be contrary to public policy, and so forth.

Now, one way of interpreting this list might be to say that it is as important not to patent anything on it as it is to patent things that are off it. On this approach, any doubts about whether or not a patent application claims a mere "discovery" rather than a true "invention" - something found in the natural order, rather than a man-made change to the natural order - should be resolved by dismissing the application. But this does not happen. Instead, the approach is to construe what is patentable generously, and what is not patentable - an exception - narrowly. ${ }^{19}$ In other words, when in doubt, create and reinforce property; do not deny it or cut it back.

(2) Reification also gives legislators a strong reason not to trim back any intellectual property right once it has been granted by statute or regulation. If the rights are property, trimming them back in any way looks like state confiscation - an immoral, if not illegal, act if compensation is not offered to the property holder.

Note the curiously asymmetrical assumption here. It is that the public has no right to be free of intellectual property, so that stopping people from doing what they could have freely done before, or requiring them now to pay, does not take away any property rights of theirs. Property language thus weights the relative morality of increasing or decreasing intellectual property rights in favour of increase.

(3) Property language can interfere whenever intellectual property rights are balanced against other rights. Suppose a piece of art is parodied and the affected copyright holder claims infringement against the parodist. The latter may have to admit the infringement, since United Kingdom copyright law - like many others - does not include any specific parody defence. But the parodist may reply that she is exercising a

19 For example, Bristol-Myers Squibb Co v Baker Norton Pharmaceuticals Inc [1999] RPC 253, 274 (affirmed by CA, 23 May 2000) following and adopting European practice. 
fundamental human right, her right to freedom of expression, protected under Article 10 of the European Convention on Human Rights 1950 ("ECHR") and many other national constitutions. We might say that here are two at least equally important rights in conflict and a balance must fairly be struck between them to encourage the different forms of creativity they entail.

But treat copyright as property, and the balancing exercise changes. We now have a mere freedom conflicting with a property right. Maybe the balance will not start off tipped by this reformulation - but place no bets.

A Canadian case provides a vivid example. The Michelin Tire Co sued a union for infringing Michelin's copyright by using a caricature of the Michelin Man logo on the leaflets the union handed out during a labour dispute. The union's defence that it was exercising its freedom of expression, guaranteed by the Canadian Charter of Rights and Freedoms, was dismissed by the court. Free speech does not entitle anybody to tread on a property right, here copyright. The union could have found some non-infringing way to express itself. The fact that way may have been less effective did not matter ${ }^{20}$ The court let a constitutionally protected right - free expression - be trumped by a right that is not even mentioned in the Canadian Charter, namely, property. That a similar approach may be taken to Article 10 of the ECHR is certainly arguable.

(4) Finally, the "broad grant, narrow exception" rule that applies to interpreting statutes is also much in evidence when lawmakers are lobbied for new intellectual property rights. It seems easier to justify widening an existing right and eliminating an exception, than it is to justify inserting an exception or widening an existing exception. Widening a right, after all, can rely for its justification on a number of aphorisms "nobody should reap without sowing", "what is worth copying is prima facie worth protecting", and the like - the attraction of which eclipses their opposites: "everyone should reap without sowing", "what is worth copying prima facie deserves to be copied", and the like. The assumption that no or less sowing would occur without the security of an intellectual property right is rarely supported by solid empirical evidence. Typically the evidence is the other way, for the quest for new protection usually occurs well after the time when businesses have already sown and harvested many crops, and when they were aware that intellectual property protection was non-existent or at best shaky.

The process of broadening rights and narrowing or eliminating exceptions is nevertheless well under way worldwide. In 1980, the United States Supreme Court allowed the patenting of a man-made oil-eating bacterium designed to clear oil spills at

20 Michelin $v$ CAW Canada (1996) 71 CPR 3d 348. See further Spence "Intellectual Property and the Problem of Parody" (1998) 114 LQR 594. 
sea. The court said that the bacterium qualified under Congressional language indicating that "anything under the sun that is made by man" is patentable subject-matter, language that necessarily included life forms. ${ }^{21}$ That language has become the new rallying cry of the US courts and US Patent Office. Overturning prior court-made exceptions, they have allowed the patenting of new transgenic life forms (not only bacteria but multicellular life forms including mice and much larger animals), computer programs (for what are these but the electronic version of mechanical parts?), ${ }^{22}$ and business schemes - so far only those implemented by a computer program ${ }^{23}$ but, on past history, that qualification will surely go, for "anything under the sun made by man" must include the "best laid schemes o' men" (if not mice), however laid.

Meanwhile, Europe and other regions are engaged in a game of catch-up, fearing that somehow they will be left behind if their intellectual property laws are not at least as protective as, if not more than, those of the United States. ${ }^{24}$ Thus, a EU Directive to allow the patenting of computer programs is in course of preparation, even though computer programs seem adequately protected under copyright law, and even though the case for granting cumulative protection that inhibits even independent development of a substantially similar program for twenty years - more than the entire conceivable life of most such programs - seems unproven.

I conclude with three points.

First, something needs to be done about these tendencies. The recent expansion of intellectual property has come to be more an end in itself than a means to the end of stimulating desirable innovation. The question whether existing protections should be scaled back or recontoured, because the activities that they supposedly foster would occur anyway and would be more widely distributed throughout society, is hardly asked any more. If intellectual property were seen as a form of subsidy - a willingness by society at large to provide economic benefits to one sector in return for the prospect of larger benefits to all - then few would question the need to keep intellectual property under constant review to ensure the scheme was working well. It would not be enough to say that intellectual property as a whole was returning social benefits that outweighed its costs as a

21 Diamond v Chakrabarty (1980) 447 US 303.

22 In Re Alappat (1994) 33 F 3d 1526 (Fed Cir).

23 State Street Bank \& Trust Co v Signature Financial Group Inc (1998) 149 F 3d 1368; contrast Merrill Lynch's Application [1989] RPC 561 (CA).

24 See, for example, UNICE Stimulating Creativity and Innovation in Europe: Benchmarking Report 2000 (Brussels, 2000) which explicitly uses the United States as a major example of desirable intellectual property policy and practice, passim. 
whole. As with any other subsidy, each element within the scheme would need to be examined to see if it passes its own A level - and with distinction. A strong case for such systematic reviews must surely exist.

Secondly, intellectual property cannot be treated as an absolute value. As I have argued elsewhere, against it: ${ }^{25}$

are ranged values of at least equal importance: the right of people to imitate others, \to work, compete, talk, and write freely, and to nurture common cultures. The way intellectual property should be reconciled with these values - or vice versa - has changed much over time and continues to vary among countries and among legal systems. The adjustments occur for social and economic reasons; they are not preordained by natural law. Where a particular line should be drawn can certainly not be answered by circularities like "intellectual property is property...

The pressure for greater intellectual property protection suggests the suppression of other values and a drift toward a competitive system in which the entrepreneur seems to be, like Robert Burns' famous mouse, ${ }^{26}$ a "wee, sleeket, cowran, tim'rous beastie" with "panic in [its] breastie" - atremble that his or her business scheme would "gang aft agley" unless he or she is clad in legal armour to withstand the onslaughts of the twin ploughs of imitation and competition.

But the entrepreneur's situation differs from that of Burns' mouse and farmer in two key respects. The mouse's panic was an isolated trauma caused by the accidental overturn of its nest by the farmer's plough; the entrepreneur's emotional state, by contrast, seems systemic: that of the perpetually "tim'rous foe, and suspicious friend". ${ }^{27}$ And whereas the modern entrepreneur demands an entitlement to the entire harvest without exception, Burns' farmer does not insist on reaping everything he has sown: "I'll get a blessing wi' the lave / An' never miss't!" The farmer does not begrudge the mouse's supping on the occasional ear of corn, for there is still plenty enough left over for the farmer to profit from.

There is a lesson here for today's entrepreneur. Possessing a right does not mean that it is a good idea to enforce it always, and to the hilt. Discretion may be nine parts of possession.

Thirdly, for the intellectual property system to survive, it must gain and keep public respect. To be respected, it must be known. To be known, it must be understood. To be

25 Intellectual Property, above n 14, 5-6.

26 Robert Burns To a Mouse On Turning Her up in Her Nest with the Plough, November 1785.

27 Alexander Pope Epistle to Dr Arbuthnot, 1. 206. 
understood, it must be coherent and persuasive. There are now calls that the public should become better educated about intellectual property. Such calls are, naturally, music to the ears of any educator. But one must be prepared for the consequence that an educated public is entitled to demand greater coherence and persuasiveness from the intellectual property system than that system presently exhibits. If those calls are not met and answered, then greater knowledge will not produce greater public respect, but instead cynicism, disregard and avoidance. Perhaps that is the first lesson which those who would educate the public may wish to teach themselves. 